\title{
Mineral Composition of 10 Tropical Forage Grasses in Puerto Rico'
}

\author{
J. A. Arroyo-Aguili and J. Coward-Lord? \\ INTRODUCTION
}

A study was undertaken to determine the calcium (Ca), phosphorus $(\mathrm{P})$, magnesium $(\mathrm{Mg})$, and potassium $(\mathrm{K})$ contents of tropical forage grasses. Limited data are available on mineral composition of tropical forages as they advance in age from 30 to 180 days.

Vicente-Chandler et al. (25) observed that $\mathrm{Ca}, \mathrm{P}, \mathrm{Mg}$, and $\mathrm{K}$ contents in Guinea (Panicum maximum) grass decreased with advance in plant age from 40 to 90 days. Similar results were obtained by Vicente-Chandler et al. (24) in Pangola (Digitaria decumbens) grass at growth stages of 30, 45 , and 60 days. In Congo (Brachiaria ruziziensis) grass (26), P and $\mathrm{K}$ contents decreased sharply with advance in plant age; however, plant age had no appreciable effect on the $\mathrm{Ca}$ or $\mathrm{Mg}$ contents. Similarly, SotomayorRíos et al. (21) indicated that mean P and $\mathrm{K}$ contents in tropical forage grasses decreased with advance in maturity while mean $\mathrm{Ca}$ and $\mathrm{Mg}$ contents increased from 30 to 45 days but decreased at 60 days.

\section{PROCEDURE}

The details of this experiment were described by Coward et al. $(6,7)$. Ten tropical forage grasses (African Crab, Digitaria swazilandensis; Venezuelan Elephant, Pennisetum setosum; Giant Pangola, Digitaria valida; Pangola; Signal, Brachiaria brizantha; Buffel, Cenchrus ciliaris; Jaragua, Hyparrhenia rufa; Limpo, Hemarthria altissima; Congo; and Guinea), lightly fertilized with $\mathrm{NH}_{4} \mathrm{NO}_{3}$ at the rate of $350 \mathrm{~kg} / \mathrm{ha}$, were harvested by hand (using a machete) at 30 -day intervals up to 180 days of age. The samples were harvested from established $10 \mathrm{~m}^{2}$ plots at the College of Agricultural Sciences, University of Puerto Rico at Mayagüez. Oven-dried $\left(60^{\circ} \mathrm{C}\right)$, ground samples were analyzed for $\mathrm{Ca}(11), \mathrm{P}(18), \mathrm{Mg}(11)$, and $\mathrm{K}$ (18). Chemical data included crude protein (CP) and total ash (A) (7) and acid-detergent fiber (ADF), permanganate lignin (L), cellulose (C), and in vitro true digestibility (IVTD) (6). Soluble ash (SA) was calculated as the difference between $A$ and insoluble ash (9).

1 Manuscript submitted to Editorial Board March 12, 1974.

2 Associate Nutritionist, Animal Husbandry Department, Agricultural Experiment Station, University of Puerto Rico, Rio Piedras, P.R., and Assistant Professor of Pastures, Animal Husbandry Department, Faculty of Agronomy, University of Costa Rica, San José, Costa Rica. 
The data were subjected to variance, simple correlation and regression analyses (20).

\section{RESULTS AND DISCUSSION}

Data on $\mathrm{Ca}, \mathrm{P}, \mathrm{Mg}$, and $\mathrm{K}$ contents of 10 forage grasses at 6 plant ages and their interrelationships and relationships with other nutrients are presented in table 1.

\section{CALCIUM}

Calcium is a mineral element required for the maintenance, growth, reproduction, and milk or beef production of animal species. Ruminant

TABLE 1.-Mean calcium, phosphorus, magnesium, and potassium contents of 10 tropical forage grasses 1

\begin{tabular}{|c|c|c|c|c|}
\hline Species & Calcium & Phosphorus & Magnesium & Potassium \\
\hline & \multicolumn{4}{|c|}{ Percent } \\
\hline African Crab & $0.22^{\text {abo }}$ & $0.19^{a}$ & $0.27^{a b}$ & $2.57 \mathrm{ab}$ \\
\hline Venezuelan Elephant & $.20^{\mathrm{abd}}$ & .17 abed & $.30^{\mathrm{a0}}$ & $3.03^{2}$ \\
\hline Giant Pangola & $.18^{\mathrm{ba}}$ & $.14^{\text {bot }}$ & $.32^{\text {cdef }}$ & $2.50^{\mathrm{ab}}$ \\
\hline Pangola & .25 .0 & $.19 \circ z$ & $.23^{b a}$ & $1.66^{\circ}$ \\
\hline Signal & $.20^{\mathrm{abi}}$ & $.18^{a h}$ & $.24^{\mathrm{bgh}}$ & $2.38^{\mathrm{ac}}$ \\
\hline Buffel & $.16^{\mathrm{bo}}$ & $.13^{\circ}$ & $.23^{\mathrm{bgi}}$ & $2.96^{\mathrm{a}}$ \\
\hline Jaragua & $.33 \mathrm{~g}$ & $.17 \mathrm{afe}$ & $.28^{\text {achi }}$ & $1.94^{\mathrm{bc}}$ \\
\hline Limpo & $.15^{\operatorname{cdt} t}$ & $.13^{\circ}$ & $.20 \mathrm{z}$ & $1.85^{b c}$ \\
\hline Congo & $.23^{a b b}$ & $.20 \mathrm{a}$ & $.30^{21}$ & $2.54^{\mathrm{ab}}$ \\
\hline Guinea & $.29^{\text {ogb }}$ & $.15^{\text {degh }}$ & $.36^{\mathrm{d}}$ & $2.43^{\mathrm{mo}}$ \\
\hline Mean & .22 & .16 & .27 & 2.39 \\
\hline
\end{tabular}

1 Mean values with one or more common letter(s) are not significant at the 5percent level.

animals require $\mathrm{Ca}$ and other minerals to maintain the microbial population in the rumen. A large part of the dietary $\mathrm{Ca}$ and $\mathrm{K}(22)$ retained by the animals is deposited in the bones.

Natural foods (12) such as forage grasses and grains are the primary sources of $\mathrm{Ca}$ and most minerals. Forages vary considerably in their mineral content and grains are low in some. Calcium is generally present in adequate quantities in forage grasses in Puerto Rico, especially in properly managed grasses. Otherwise, it can be increased in grasses by heavy liming (27).

The Ca content (table 1) revealed highly significant differences ${ }^{3}$ with respect to species. Calcium values per species per age ranged from 0.11 to 0.43 percent. The Ca content of temperate forages (22) varies from 0.28

a Significant at the 1-percent level. 
to 2.50 percent. Buffel grass exhibited the lowest $\mathrm{Ca}$ content ( 0.17 percent) and Jaragua grass the highest ( 0.43 percent) of all grass species at 30 days. At 180 days, Buffel and Giant Pangola grasses presented the lowest $(0.13$ percent) and African Crab grass the highest ( 0.38 percent) values in $\mathrm{Ca}$ content, respectively. In tropical grasses in Brazil, Gomide et al. (10) obtained a range in $\mathrm{Ca}$ content from 0.24 to 0.84 percent.

Plant ages from 30 to 180 days (table 2) did not reveal any significant differences ${ }^{4}$ in $\mathrm{Ca}$ content even though there was a decline in mean $\mathrm{Ca}$ content up to the 90-day stage. No significant correlations (table 3) were obtained between $\mathrm{Ca}$ content and each of the other parameters: $\mathrm{K}, \mathrm{P}, \mathrm{Si}$, SA, CP, ADF, L, C, IVTD, and age. Magnesium content was the only parameter significantly associated to Ca. In Surinam, Appelman and Dir-

TABLE 2.-Mean calcium, phosphorus, magnesium, and potassium contents and calcium to phosphorus ratio at six different ages

\begin{tabular}{rrrrrr}
\hline Ages & Calcium & Phosphorus & Magnesium & Potassium & $\begin{array}{c}\text { Calcium to } \\
\text { phosphorus ratio }\end{array}$ \\
\hline Days & \multicolumn{2}{c}{ Percent } \\
30 & 0.24 & 0.27 & 0.37 & 4.99 & $0.89: 1$ \\
60 & .22 & .20 & .31 & 3.10 & $1.10: 1$ \\
90 & .18 & .15 & .23 & 2.09 & $1.20: 1$ \\
120 & .21 & .13 & .24 & 1.70 & $1.62: 1$ \\
150 & .20 & .12 & .24 & 1.43 & $1.67: 1$ \\
180 & .27 & .12 & .24 & 1.01 & $2.25: 1$ \\
Mean & .22 & .16 & .27 & 2.39 & $1.38: 1$ \\
\hline
\end{tabular}

ven (1) did not obtain a decline in Ca content with plant age from 21 to 56 days in Elephant (Pennisetum purpureum), Guatemala (Tripsacum laxum), Para (Brachiaria mutica), and Pangola grasses. Similar trends, although at higher levels, were observed by Tergas et al. (23) with Jaragua grass in Costa Rica, where $\mathrm{Ca}$ concentrations decreased until flower formation at 84 days of age. Gomide et al. (10) observed a tendency for the Ca content to decrease with plant age from 28 to 252 days in Elephant and Kikuvu (Pennisetum clandestinum) grasses. In Elephant grass, Prospero and Peixoto (17) in Brazil indicated that the highest $\mathrm{Ca}$ concentration was observed in the dry season and when the forages were in advanced stage of maturity.

Dietary Ca requirements vary from 0.16 to 0.60 percent (14) for beef and from 0.14 to 0.50 percent (15) for dairy cattle depending on growth and/or production stage of the animal. Dairy cattle (12) need approxi-

4 Significant at the 5-percent level. 
mately 0.25 percent $\mathrm{Ca}$ in the total ration (air dry) to meet requirements for growth and maintenance; lactating cows require 0.30 to 0.40 percent $\mathrm{Ca}$ in the dry ration.

The Ca values obtained in this study tended to be comparatively lower than those of others $(1,10,17,23)$, probably due to the unlimed state of the soils. Bonnet and Riera (3) indicated that when lime, or lime and $P$ were applied, there was a highly significant increase of $\mathrm{Ca}$ and $\mathbf{P}$ in the grasses.

\section{PHOSPHORUS}

Like Ca, $P$ (22) is a constituent of bones. Rapidly-growing animals require proportionately larger amounts of $\mathrm{P}$ than adults. All forms of $\mathrm{P}$ seemed to be about 70 percent available to the ruminant.

TABLE 3.-Simple correlations among mineral and nutrient composition of 10 forage grasses at 6 ages

\begin{tabular}{ccccccc}
\hline Constituent & $\mathrm{Ca}^{1}$ & $\mathrm{Mg}$ & $\mathrm{P}$ & $\mathrm{Si}$ & $\mathrm{SA}$ & \\
\hline $\mathrm{K}$ & -0.06 & $.66^{* * 2}$ & $.77^{* *}$ & $-.27^{* 3}$ & $.94^{* *}$ & \\
$\mathrm{Ca}$ & - & $.33^{*}$ & .16 & .25 & .08 &. \\
$\mathrm{Mg}$ & - & - & $.60^{* *}$ & -.05 & $.69^{* *}$ & \\
$\mathrm{P}$ & - & - & - & $-.29^{*}$ & $.86^{* *}$ & \\
& & & & $\mathrm{C}$ & IVTD & Age \\
$\mathrm{Ca}$ & $\mathrm{CP}$ & $\mathrm{ADF}$ & $\mathrm{L}$ & $\mathrm{C}$ & .05 & .06 \\
\hline
\end{tabular}

$1 \mathrm{Ca}$, calcium; Mg, magnesium; P, phosphorus; Si, silica; SA, soluble ash; $\mathrm{K}$, potassium; CP, crude protein; ADF, acid-detergent fiber; L, lignin; C, cellulose; IVTD, in vitro true digestibility.

2** Significant at the 1-percent level.

3 * Significant at the 5-percent level.

Highly significant differences were obtained in $\mathrm{P}$ content (table 1) with regard to species. Phosphorus values per species per age ranged from 0.08 to 0.39 percent. Buffel and Congo grasses exhibited the lowest (0.19 percent) and the highest ( 0.39 percent) $P$ values of all grasses at 30 days, respectively. At 180 days, Limpo and African Crab grasses presented the lowest $(0.08$ percent) and the highest $(0.16$ percent) $P$ values, respectively. Sullivan (22) indicated that the $P$ content of temperate forages ranges from about 0.14 to 0.50 percent. In Brazil, (10) $P$ content varied from 0.07 to 0.38 percent.

Harvest intervals from 30 to 180 days of age (table 2) revealed highly significant differences in P content. Highly significant correlations (tables 3 and 4) were obtained between $P$ and the following parameters: $\mathrm{K}, \mathrm{Mg}$, age, CP, ADF, L, C, IVTD, and SA. Phosphorus decreases as K, Mg, SA, $\mathrm{CP}, \mathrm{IVTD}$, and $\mathrm{A}$ decrease and as $\mathrm{Si}$, age, $\mathrm{ADF}, \mathrm{L}$, and $\mathrm{C}$ increase, indicat- 
TABLE 4.-Regression equations of form $\mathrm{Y}=\mathrm{a}+\mathrm{bX}$ for estimating mineral composition $(\mathrm{Y})$ from nutrient composition $(\mathrm{X})$

\begin{tabular}{|c|c|c|c|}
\hline Variables correlated ${ }^{1}$ & Intercept & $\begin{array}{l}\text { Coefficient of } \\
\text { regression }\end{array}$ & $\begin{array}{l}\text { Coefficient of } \\
\text { correlation }\end{array}$ \\
\hline & a & $b$ & $r$ \\
\hline \multicolumn{4}{|l|}{ Percent $\mathrm{P}(Y)$ with: } \\
\hline Age & 0.272 & -0.001 & $-0.78^{* * 2}$ \\
\hline $\mathrm{CP}$ & .087 & .012 & $.84^{* *}$ \\
\hline ADF & .562 & .009 & $-.70^{* *}$ \\
\hline $\mathbf{L}$ & .409 & .031 & $-.82^{* *}$ \\
\hline $\mathbf{C}$ & .454 & -.008 & $-.49^{* *}$ \\
\hline IVTD & -.142 & .005 & $.82^{* *}$ \\
\hline A & .0003 & .022 & $.72^{* *}$ \\
\hline \multicolumn{4}{|l|}{ Percent $\operatorname{Mg}(Y)$ with: } \\
\hline Age & .359 & .001 & $-.54^{* *}$ \\
\hline $\mathrm{CP}$ & .209 & .009 & $.57^{* *}$ \\
\hline ADF & .469 & .004 & $.29 * 3$ \\
\hline L & .473 & .026 & $-.57 * *$ \\
\hline IVTD & .086 & .003 & $.42^{* *}$ \\
\hline A & .088 & .024 & $.67^{* *}$ \\
\hline \multicolumn{4}{|l|}{ Percent $\mathbf{K}(Y)$ with: } \\
\hline Age & 4.912 & -.024 & $-.82^{* *}$ \\
\hline $\mathrm{CP}$ & .447 & .283 & $.87^{* *}$ \\
\hline ADF & 9.842 & .162 & $-.57^{* *}$ \\
\hline $\mathbf{C}$ & 7.564 & -.147 & $-.38 * *$ \\
\hline $\mathbf{L}$ & 7.234 & .627 & $-.71^{* *}$ \\
\hline IVTD & -4.015 & .113 & $.73^{* *}$ \\
\hline A & -1.990 & .573 & $.81^{* *}$ \\
\hline \multicolumn{4}{|l|}{ Percent SA $(Y)$ with: } \\
\hline Age & 8.441 & -.035 & $-.83^{* *}$ \\
\hline $\mathrm{CP}$ & 1.995 & .411 & $.90^{* *}$ \\
\hline ADF & 16.311 & .250 & $-.62^{* *}$ \\
\hline $\mathbf{L}$ & 12.414 & .984 & $-.79 * *$ \\
\hline C & 12.625 & -.222 & $-.41 * *$ \\
\hline IVTD & -4.882 & .171 & $.78^{* *}$ \\
\hline $\mathbf{A}$ & -1.813 & .866 & $.87^{* *}$ \\
\hline \multicolumn{4}{|l|}{$\mathrm{Ca}: \mathrm{P}(Y)$ with: } \\
\hline Age & .554 & .009 & $.64^{* *}$ \\
\hline
\end{tabular}

${ }^{3} \mathrm{P}$, phosphorus; $\mathrm{Mg}$, magnesium; $\mathrm{K}$, potassium; $\mathrm{SA}$, soluble ash; $\mathrm{CP}$, crude protein; ADF, acid-detergent fiber; L, lignin; C, cellulose; IVTD, in vitro true digestibility; A, ash.

$2 *$ * Significant at the 1-percent level.

* Significant at the 5-percent level.

ing a decrease in nutritive value with advance in maturity. Sullivan (22) stated that $P$ was higher in young rapidly growing tissue than in older tissue. Similar results were obtained by Gomide et al. (10) in Brazil, where mean $P$ content was highest ( 0.26 percent) at 28 days and decreased with 
advance in plant age up to 252 days of age (0.12 percent). Prospero and Peixoto (17) also observed a decline in mean $P$ content from 45 days $(0.21$ percent) to 315 days (0.04 percent).

Dietary $P$ requirements vary from 0.16 to 0.43 percent (14) for beef and from 0.14 to 0.38 percent (15) for dairy animals. Dairy cattle require approximately 0.25 percent $P$ in the ration for growth, maintenance, and lactation.

\section{CALCIUM TO PHOSPHORUS RATIO}

Calcium and $P$ (13) are so closely related in nutrition that a dietary deficiency or excess of one may seriously interfere with the utilization of the other.

Smith and Loosli (19) indicated that ruminant animals can tolerate a rather wide difference in the $\mathrm{Ca}$ to $\mathrm{P}$ ratio without harm, as if often the case in alfalfa hay (8 $\mathrm{Ca}$ to $1 \mathrm{P}$ ). The National Research Council bulletin on dairy cattle (15) concluded that growth rate and feed utilization were entirely satisfactory within a Ca to $\mathrm{P}$ ratio of 1 to 1 to 7 to 1 . More recently, Hillman et al. (12) indicated that the $\mathrm{Ca}$ to $\mathrm{P}$ ratio in the total ration of dairy cows should not be below 1 to 1 nor above 3 to 1 , for too wide or too close $\mathrm{Ca}$ to $\mathrm{P}$ ratios may help induce milk fever.

Deficiencies of $\mathrm{Ca}$ and $\mathrm{P}$ (4) are overcome by supplemental feeding of products such as bonemeal, dicalcium phosphate, monocalcium phosphate, and defluorinated rock phosphate. Both limestone and oyster shells $(4,19)$, forms of calcium carbonate, provide only $\mathrm{Ca}$ whereas disodium phosphate supplies $\mathbf{P}$ only. The amounts and proportions of the supplement to be fed depend somewhat upon other ration ingredients, particularly the nature and amount of the roughage.

The best procedure (4) to insure that dairy animals receive and consume enough $\mathrm{Ca}$ and $\mathrm{P}$ for maximum performance is to include 1 percent salt and 1 to 2 percent of an adequate mineral supplement in the grain mixture. Grazing animals not consuming concentrate feeds should be provided with minerals and salt, free-choice in separate boxes.

The range in $\mathrm{Ca}$ to $\mathrm{P}$ ratio per age (table 2) fluctuated between 0.89 and 1.38 parts $\mathrm{Ca}$ to 1 part $\mathrm{P}$, the ratio increasing as the forages advanced in age from 30 to 180 days (table 4). The $\mathrm{Ca}$ to $\mathrm{P}$ ratio per grass species ranged from 1.11 to 1.94 parts $\mathrm{Ca}$ to 1 part $\mathrm{P}$. However, considering all individual samples, the range fluctuated between 0.59 and 3.36 parts $C a$ to 1 part $P$, with the lower ratios occurring at earlier ages.

Blood $\mathrm{Ca}$ and $\mathbf{P}$ analyses (2) in dairy cattle failed to show any deficiencies throughout the northern, southern, eastern, and central regions of Puerto Rico, claimed to be apparently mineral-deficient areas. The data fell within 
the normal limits for blood serum $\mathrm{Ca}$ and $\mathrm{P}$ contents, thus probably eliminating any possibility of deficiency.

\section{MAGNESIUM}

Magnesium is a mineral element required for bone structure (22) and for muscle irritability, electrolyte balance, and enzyme action (12). Magnesium has been reported (28) as ranging from 0.06 to 0.73 percent in forages. Forages (12) containing less than 0.2 percent $\mathrm{Mg}$ may cause grass tetany especially when heavily fertilized with nitrogen and $\mathrm{K}$.

The Mg content (table 1) revealed highly significant differences between species. Magnesium values per species per age ranged from 0.15 to 0.46 percent. At 30 days, Limpo grass had the lowest $\mathrm{Mg}$ content $(0.25$ percent) while Guinea and Congo grasses had the highest ( 0.44 percent). At 180 days, Signal presented the lowest ( 0.15 percent), and Guinea the highest (0.40 percent) $\mathrm{Mg}$ content. In Brazil, Gomide et al. (10) and Prospero and Peixoto (17) obtained $\mathrm{Mg}$ values from 0.16 to 0.54 percent and from 0.10 to 0.16 percent, respectively.

Harvest intervals from 30 to 180 days of age (table 2) revealed highly significant differences in $\mathrm{Mg}$ content. Magnesium decreased significantly (tables 3 and 4) as CP, IVTD, A, P, and SA decreased and as age, ADF, and $\mathrm{L}$ increased. In Surinam (1) and in Brazil (17), $\mathrm{Mg}$ content remained on the same level as forages advanced in age. However, Gomide et al. (10) obtained significant decreases in $\mathrm{Mg}$ content with advance in plant age from 28 to 252 days.

Dietary $\mathrm{Mg}$ requirements for both beef and dairy cattle vary from 12 to $30 \mathrm{mg}$ per $\mathrm{kg}$ of body weight per day $(14,15)$. Lactating dairy cows $(12)$ require 0.15 to 0.20 percent of $\mathrm{Mg}$ in the dry ration.

\section{POTASSIUM}

Potassium (5) is known to be one of several elements concerned with nerve irritability. It is essential for maintaining the acid-base balance, the osmotic pressure in intracellular fluids, and the electrolyte balance (12).

Sullivan (22) indicated that the $\mathrm{K}$ content of temperate forages is usually between 1 and 4 percent. The amount decreases with the age of the plant and is controlled in most part by quantities available in the soil.

Significant differences in $\mathrm{K}$ content were obtained between species (table 1). Potassium values per species per age ranged from 0.68 to 7.33 percent. At 30 days, Limpo and Venezuelan Elephant grasses had the lowest (3.00 percent) and the highest (7.33 percent) $K$ contents, respectively. At 180 days, Pangola presented the lowest ( 0.68 percent), and African Crab grass the highest (1.27 percent) $\mathrm{K}$ content. Mean $\mathrm{K}$ content ranged from 0.45 
to 0.36 percent and from 1.67 to 2.66 percent in Guinea (25) and in Congo (26) grass.

Harvest intervals from 30 to 180 days of age (table 2) exhibited highly significant differences in $\mathrm{K}$ content. Potassium decreased significantly (tables 3 and 4) with decreases in Mg, P, SA, CP, IVTD, and A with increases in $\mathrm{Si}$, age, $\mathrm{ADF}, \mathrm{L}$, and $\mathrm{C}$. As forage grasses advanced in plant age from 30 to 90 days, Vicente-Chandler et al. (26) obtained a reduction in $\mathrm{K}$ content in Congo grass. Similar results with advance in plant age were obtained by Appelman and Dirven in Surinam (1) and by Gomide et al. in Brazil (10).

Beef cattle (8) require between 0.67 and 0.77 percent $\mathrm{K}$. Pradhan and Hemken (16) reported that 0.81 percent $\mathrm{K}$ appeared to be adequate for lactating dairy animals. Potassium deficiency is not believed to be a common problem in ruminants, due to the high $\mathrm{K}$ content of most forages.

\section{SOLUBLE ASH}

Since Si is present in the A fraction, and more specifically in the insoluble ash fraction, the A content (22) may be a misleading criterion of $\mathrm{Ca}, \mathrm{P}$, $\mathrm{Mg}$, and $\mathrm{K}$ contents. The SA fraction (22) contains most of the nutritionally important elements, and is correlated in a highly significant manner to age, ADF, L, and C but directly correlated to CP and IVTD (table 4).

It may be concluded that $\mathrm{P}, \mathrm{Mg}$, and $\mathrm{K}$ levels, but not $\mathrm{Ca}$, declined with advance in plant age and that apparently contents of all four minerals were adequate for beef and dairy animals in Puerto Rico. The $\mathrm{Ca}$ to $\mathrm{P}$ ratios seemed generally adequate, although somewhat low at younger growth stages.

\section{SUMMARY}

Mineral composition-calcium (Ca), phosphorus $(\mathrm{P})$, magnesium $(\mathrm{Mg})$, and potassium $(\mathrm{K})$-in 60 samples of forage grasses representing 10 forages (African Crab, Digitaria swazilandensis; Venezuelan Elephant, Pennisetum setosum; Giant Pangola, Digitaria valida; Pangola, Digilaria decumbens; Signal, Brachiaria brizantha; Buffel, Cenchrus ciliaris; Jaragua, Hyparrhenia rufa; Limpo, Hemarthria altissima; Congo, Brachiaria ruziziensis; and Guinea, Panicum maximum) at 6 growth stages was analyzed statistically by variance, simple correlation, and simple regression analyses.

Calcium, $\mathrm{P}$, and $\mathrm{Mg}$ contents revealed highly significant differences while $\mathrm{K}$ presented significant differences with respect to grass species. Phosphorus, $\mathrm{Mg}$ and $\mathrm{K}$ contents, but not $\mathrm{Ca}$, presented highly significant differences with respect to plant ages. Values ranged from 0.11 to 0.43 percent for $\mathrm{Ca}, 0.08$ to 0.39 percent for $\mathrm{P}, 0.15$ to 0.46 percent for $\mathrm{Mg}$, and 
0.68 to 7.33 percent for $K$. Calcium to $P$ ratio ranged from 0.89 to 1.38 parts $\mathrm{Ca}$ to 1 part $\mathrm{P}$, increasing as forages advanced in age.

Phosphorus, $\mathrm{Mg}, \mathrm{K}$, and $\mathrm{SA}$, but not $\mathrm{Ca}$, were associated in a highly significant way to age, crude protein, lignin, in vitro true digestibility, and total ash. Phosphorus, $\mathrm{K}$, and soluble ash were associated in a highly significant way to acid-detergent fiber and cellulose; $\mathrm{Mg}$ was significantly associated to acid-detergent fiber.

It may be concluded that $\mathrm{P}, \mathrm{Mg}$, and $\mathrm{K}$, but not $\mathrm{Ca}$, declined with advance in plant age and that apparently the mineral composition of the grasses studied is nutritionally adequate for beef and dairy animals in Puerto Rico. The $\mathrm{Ca}$ to $\mathrm{P}$ ratios seemed generally adequate; however, they were somewhat low at younger growth stages. Additional mineral supplementation, either free-fed or mixed with the feed, is a routine feeding practice to insure optimum mineral intake.

\section{RESUMEN}

La composición mineral-calcio $(\mathrm{Ca})$, fósforo $(\mathrm{P})$, magnesio $(\mathrm{Mg})$ y potasio $(\mathrm{K})$ de 60 muestras de 10 yerbas forrajeras ("African Crab", Digitaria swazilandensis; Elefante Venezolana, Pennisetum setosum; Pangola Gigante, Digitaria valida; Pangola, Digitaria decumbens; Signal, Brachiaria brizantha; Buffel, Cenchrus ciliaris; Jaragua, Hyparrhenia rufa; Limpo, Hemarthria altissima; Congo, Brachiaria ruziziensis y Guinea, Panicum maximum) a 6 edades de crecimiento se analizó estadísticamente por análisis de varianza, correlación y regresión simple.

El Ca, el $\mathrm{P}$ y el $\mathrm{Mg}$ arrojaron diferencias altamente significativas mientras que el $K$ presentó diferencias significativas con respecto a las especies. En el caso del $\mathbf{P}$, el $\mathrm{Mg}$ y el $\mathrm{K}$, pero no del $\mathrm{Ca}$, las diferencias fueron altamente significativas con respecto a las edades de las yerbas. Los valores variaron de 0.11 a 0.43 por ciento para el $\mathrm{Ca}$, de 0.08 a 0.39 por ciento para el $\mathrm{P}$, de 0.15 a 0.46 por ciento apra el $\mathrm{Mg}$ y de 0.68 a 7.33 por ciento para el $\mathrm{K}$. La proporción de $\mathrm{Ca}$ a $\mathrm{P}$ varí́ de 0.89 a 1.38 partes de Ca a 1 parte de $P$, aumentando con la edad de los forrajes.

$\mathrm{El} \mathrm{P}$, el $\mathrm{Mg}$, el $\mathrm{K}$ y la ceniza soluble, pero no el $\mathrm{Ca}$, se asociaron en forma altamente significativa con la edad, la lignina, la digestibilidad in vitro y la ceniza total. El $P$, el $\mathrm{K}$ y la ceniza soluble se asociaron en forma altamente significativa con la fibra ácido-detergente.

Se puede concluir que el $\mathrm{P}$, el $\mathrm{Mg}$ y el $\mathrm{K}$, pero no el $\mathrm{Ca}$, disminuyeron con la edad de las forrajeras y que, aparentemente, el contenido mineral de las yerbas bajo estudio llena los requisitos nutrimentales del ganado de léche y de carne. La proporción de $\mathrm{Ca}$ a $\mathbf{P}$ pareció generalmente adecuada, aunque fue relativamente más baja en las etapas tempranas de crecimiento de estas yerbas. El suplemento mineral adicional, suministrado a discreción del animal o mezclado con el alimento concentrado, es una práctica rutinaria de alimentación para garantizar el consumo mineral optimo.

\section{LITERATURE CITED}

1. Appelman, H., and Dirven, J. G. P., The influence of the cutting interval on the chemical composition of various grasses, De Surinaamse Landbouw 10: 95-102, 1962. 
2. Arroyo-Aguilú, J. A., unpublished data, 1956.

3. Bonnet, J. A., and Riera, A. R., Tracing the mineral from the soil to the plant to the animal blood, III. The effect of phosphorus and lime on the mineral composition of the soil and grass, J. Agr. Univ. P.R. 33(2): 57-65, 1949.

4. Buck, G. R., and Griefe, D. G., Minerals for dairy cattle, Ontario Ministry of Agriculture and Food Factsheet, AGDEX 410/65, 1973.

5. Church, D. C., Digestive Physiology and Nutrition of Ruminants, 2, Nutrition, O.S.U. Bookstores, Inc., Corvallis, Ore., 1971.

6. Coward-Lord, J., Arroyo-Aguilú, J. A., and García-Molinari, O., Fibrous carbohydrate fractions and in vitro true and apparent digestibility of 10 tropical forage grasses, J. Agr. Univ. P.R. 58(3): 293-304, 1974.

7.,-- , and - , Proximate nutrient composition of 10 tropical forage grasses, J. Agr. Univ. P.R. 58(3): 305-11, 1974.

8. Devlin, T. J., Roberts, W. K., and St. Omer, V. V. E., Effects of dietary potassium upon growth, serum electrolytes and intrarumen environment of finishing beef steers, J. Anim. Sci. 28: 557-62, 1969.

9. Goering, H. K., and Van Soest, P. J., Forage fiber analyses (apparatus, reagents, procedures and some applications), USDA. Agr. Handbook 379, 1970.

10. Gomide, J. A., Noller, C. H., Mott, G. O., Conrad, J. H., and Hill, D. L., Mineral composition of six tropical grasses as influenced by plant age and nitrogen fertilization, Agron. J. 61: 120-3, 1969.

11. Greweling, T., An extraction procedure for the determination of total calcium, magnesium, and potassium in plant tissue, J. Agr. Food. Chem. 10: 138-40, 1962.

12. Hillman, D., Huber, J. T., Emery, R. S., Thomas, J. W., and Cook, R. M., Basic dairy cattle nutrition, Mich. State Univ, Ext. Bull. E-702, 1973.

13. Moon, R. R., Minerals for beef cattle, Ontario Ministry of Agriculture and Food Factsheet, AGDEX 420/65, 1973.

14. N. R. C., Nutrient requirements of domestic animals, 4, Nutrient requirements of beef cattle, Nat. Acad. Sci., Washington, D.C., 1970.

15. - Nutrient requirements of domestic animals, 3 , Nutrient requirements of dairy cattle, Nat. Acad. Sci., Washington, D.C., 1966.

16. Pradhan, K., and Hemken, R. W., Potassium depletion in lactating cows, J. Dairy Sci. $51:$ 1,377-81, 1968.

17. Prospero, A. O., and Peixoto, A. M., Composição mineral do capim Elefante (Penniselum purpureum, Schum.) variedade Napier, em diferentes estádios de desenvolvimiento, 0 Solo 64: 45-52, 1972.

18. Riera, A., The method of foliar diagnosis as applied to sugarcane, II. The chemical analyses of sugarcane-leaf samples, Univ. P.R., Agr. Exp. Sta. Bull. 123, 1955.

19. Smith, S. E., and Loosli, J. K., The mineral and vitamin requirements of livestock, Cornell Univ. Ext. Bull. 1149, 1970.

20. Snedecor, G. W., and Cochran, W. G., Statistical Methods, 6th ed, The Iowa State Univ. Press, Ames, Iowa, 1967.

21. Sotomayor-Ríos, A., Juliá, F. J., and Arroyo-Aguilú, J. A., Effects of harvest intervals on the yield and composition of ten forage grasses, J. Agr. Univ. P.R. 58(4) 448-55, 1974.

22. Sullivan, J. T., Chemical composition of forages with reference to the needs of the grazing animal, A review of recent research findings, ARS 34-107, USDA, 1969. 
23. Tergas, L. E., Blue, W. G., and Moore, J. E., Nutritive value of fertilized Jaragua. grass (Hyparrhenia rufa (Nees) Stapf.) in the wet-dry Pacific region of Costa Rica, Trop. Agr. (Trinidad) 48: 1-8, 1971.

24. Vicente-Chandler, J., Figarella, J., and Silva, S., Effects of nitrogen fertilization and frequency of cutting on the yield and composition of Pangola grass in Puerto Rico, J. Agr. Univ. P.R. 45(1): 37-45, 1961.

25. —,.Silva, S., and Figarella, J., Effects of nitrogen fertilization and frequency of cutting on the yield and composition of Guinea grass in Puerto Rico, J. Agr. Univ. P.R. 43(4): 228-39, 1959.

26. - - - Abruña, F., and Rodriguez, J. A., Effect of two cutting heights, four harvest intervals and five nitrogen rates on yield and composition of Congo grass under humid tropical conditions, J. Agr. Univ. P.R. 56(3): 280-91, 1972.

27. —-, Abruña, F., Caro-Costas, R., Figarella, J., Silva S., and Pearson, R. W., Intensive grassland management in the humid tropics of Puerto Rico, Univ. P.R., Agr. Exp. Sta. Bull. 233 (in press), 1974.

28. Wolton, K. M., Some factors affecting herbage magnesium levels, Proc. VIII Inter. Grassland Cong. 544-8, 1960. 